\title{
Frequency of triggering bacteria in patients with reactive arthritis and undifferentiated oligoarthritis and the relative importance of the tests used for diagnosis
}

C Fendler, S Laitko, H Sörensen, C Gripenberg-Lerche, A Groh, J Uksila, K Granfors, J Braun, J Sieper

\begin{tabular}{|c|}
\hline $\begin{array}{l}\text { Department of } \\
\text { Medicine, } \\
\text { Rheumatology, } \\
\text { Klinikum Benjamin } \\
\text { Franklin, Free } \\
\text { University, Berlin, } \\
\text { Germany } \\
\text { C Fendler } \\
\text { J Braun } \\
\text { J Sieper }\end{array}$ \\
\hline $\begin{array}{l}\text { Deutsches Rheuma- } \\
\text { forschungszentrum, } \\
\text { Berlin } \\
\text { C Fendler } \\
\text { J Sieper }\end{array}$ \\
\hline $\begin{array}{l}\text { Rheumaklinik Buch, } \\
\text { Berlin } \\
\text { S Laitko }\end{array}$ \\
\hline $\begin{array}{l}\text { Immanuel- } \\
\text { Krankenhaus, Berlin } \\
\text { H Sörensen }\end{array}$ \\
\hline $\begin{array}{l}\text { National Public Health } \\
\text { Institute, Department } \\
\text { in Turku, Finland } \\
\text { C Gripenberg-Lerche } \\
\text { K Granfors }\end{array}$ \\
\hline $\begin{array}{l}\text { Department of } \\
\text { Microbiology, Jena, } \\
\text { Germany } \\
\text { A Groh }\end{array}$ \\
\hline $\begin{array}{l}\text { Department of } \\
\text { Medical Microbiology, } \\
\text { University of Turku, } \\
\text { Finland } \\
\text { J Uksila }\end{array}$ \\
\hline $\begin{array}{l}\text { Correspondence to: } \\
\text { Professor J Sieper, } \\
\text { Rheumatology, Department } \\
\text { of Medicine, Benjamin } \\
\text { Franklin Hospital, } \\
\text { Hindenburgdamm } 30,12200 \\
\text { Berlin, Germany } \\
\text { hjsieper@zedat.fu-berlin.de }\end{array}$ \\
\hline
\end{tabular}

Accepted 17 August 2000
Abstract

Objective-Reactive arthritis (ReA) triggered by Chlamydia trachomatis or enteric bacteria such as yersinia, salmonella, Campylobacter jejuni, or shigella is an important differential diagnosis in patients presenting with the clinical picture of an undifferentiated oligoarthritis (UOA). This study was undertaken to evaluate the best diagnostic approach.

Patients and methods-52 patients with ReA, defined by arthritis and a symptomatic preceding infection of the gut or the urogenital tract, and 74 patients with possible $\operatorname{ReA}$, defined by oligoarthritis without a preceding symptomatic infection and after exclusion of other diagnoses (UOA), were studied. The following diagnostic tests were applied for the identification of the triggering bacterium: for yersinia induced $\operatorname{ReA}-$ stool culture, enzyme immunoassay (EIA), and Widal's agglutination test for detection of antibodies to yersinia; for salmonella or campylobacter induced $\operatorname{ReA}-$ stool culture, EIA for the detection of antibodies to salmonella and Campylobacter jejuni; for infections with shigella-stool culture; for infections with Chlamydia trachomatisculture of the urogenital tract, microculture of the urogenital tract, micro-
immunofluorescence and immunoperoxidase assay for the detection of antibodies to Chlamydia trachomatis.

Results-A causative pathogen was identified in $29 / 52(56 \%)$ of all patients with ReA. In $17(52 \%)$ of the patients with enteric $\operatorname{ReA}$ one of the enteric bacteria was identified: salmonella in 11/33 (33\%) and yersinia in $6 / 33$ (18\%). Chlamydia trachomatis was the causative pathogen in $12 / 19(63 \%)$ of the patients with urogenic ReA. In patients with the clinical picture of UOA a specific triggering bacterium was also identified in $35 / 74(47 \%)$ patients: yersinia in 14/74 (19\%), salmonella in 9/74 (12\%), and Chlamydia trachomatis in 12/74 $(16 \%)$.

Conclusions-Chlamydia trachomatis, yersinia, and salmonella can be identified as the causative pathogen in about $50 \%$ of patients with probable or possible $\operatorname{ReA}$ if the appropriate tests are used.

(Ann Rheum Dis 2001;60:337-343)
Reactive arthritis (ReA) is a well known complication of enteric infections caused by yersinia, salmonella, shigella, and campylobacter, or of urogenital tract infections caused by Chlamydia trachomatis. ${ }^{1}$ This form of ReA is regarded as part of the spondyloarthropathies ( and $50 \%$ of these patients. $^{2}$ The arthritis has a typical join pattern, which is also characteristic for the whole group of spondyloarthropathies: an asymmetrical arthritis predominantly of the legs. ${ }^{3}$ In most patients an oligoarthritis or monarthritis is present. Patients with such int pattern constitute up to $50 \%$ of patients in linics for early arthritis. ${ }^{4-6}$ Therefore ReA is an mportant differential diagnosis.

Despite the clinical relevance there are no established criteria available for the diagnosi of ReA. Earlier criteria relied almost exclusively on clinical indicators of a symptomatic preceding infection, such as urethritis/cervicitis, or on symptoms characteristic for the whole group of 作 ${ }^{7-9}$ the whole group of likely hat in a substantial proportion of patients with ReA the preceding infection is asymptomatic or associated with only a few symptoms, ${ }^{10}$ often labelled as undifferentiated arthritis or undifferentiated oligoarthritis (UOA). ${ }^{12}$ Better laboratory tests identifying the triggering baceria are now available $e^{13}$ and are in

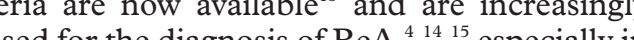

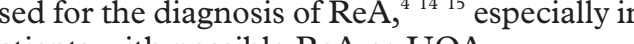
patients with possible ReA or UOA

In this study we used all available test (except polymerase chain reaction (PCR) fo the detection of bacteria in the joint) for the identification of the bacteria causing ReA in a arge number of patients with ReA (having ymptomatic preceding infection of the gut or symp gut or (UOA with a joint pattern compatible with ReA). We report the frequency of single bacteria in these two subgroups and the relative importance of the different tests used.

\section{Patients and methods}

PATIENTS' SELECTION AND CHARACTERISTICS

In this study 126 patients from different rheumatology clinics in Berlin, Germany, with a clinical diagnosis of $\operatorname{ReA}(n=52)$ or UOA $(n=74)$ were included. A diagnosis of ReA was made if patients presented with the clinical picture of an asymmetrical arthritis and a preceding symptomatic urethritis or enteritis no onger than four weeks before the onset of arthritis. A diagnosis of UOA was made after 
Table 1 Characteristics of all patients, patients with reactive arthritis (ReA), and patients with undifferentiated

\begin{tabular}{llll}
\hline & All patients & ReA & UOA \\
\hline Number & 126 & 52 & 74 \\
Age (years $\left.{ }^{\star}\right)$ & 36.6 & 35.8 & 37.4 \\
Range & $18-65$ & $18-60$ & $19-65$ \\
Sex (M/F) & $66 / 60$ & $28 / 24$ & $38 / 36$ \\
Disease duration¥ (weeks†) & 14 & 8 & 30 \\
Range & $1-354$ & $1-260$ & $2-354$ \\
HLA-B27+ (\%) & 45.2 & 57.7 & 35.1 \\
Patients with monarthritis (\%) & 42 & 35 & 47 \\
\hline
\end{tabular}

${ }^{*}$ Mean; $†$ median

AAt time of inclusion into the study.

TThe frequency of HLA-B27 in the Berlin area is 9.3\% ${ }^{47}$

exclusion of other diagnoses if an oligoarthritis (fewer than five joints affected), either asymmetrically or predominantly of the legs, was present and the criteria for ReA were not fulfilled. Other diagnoses were excluded by appropriate tests. Table 1 shows the patients' characteristics. Some of these patients were later included in a treatment trial with antibiotics. ${ }^{16}$

SEROLOGY

In all serological tests used (except the Widal test) antibodies of different immunoglobulin classes, $\operatorname{IgM}, \operatorname{IgG}$, and $\operatorname{IgA}$, were investigated. Antibodies to Yersinia enterocolitica O:3 and O:9 and Yersinia pseudotuberculosis I and III were studied by enzyme immunoassay (EIA) ${ }^{17}$ and agglutination test (Widal), and to Salmonella More than $90 \%$ of cases with salmonella More than $90 \%$ of cases with salmonella
triggered ReA are caused by salmonellae that triggered $\mathrm{ReA}$ are caused by salmonellae that
have $\mathrm{O}$ antigens in common with these two species (serotypes B and D). ${ }^{19}$ The remaining salmonellae with different $\mathrm{O}$-specific polysaccharide have a lipid A core and other components that are similar to the corresponding components of serotypes $\mathrm{B}$ and $\mathrm{D}$, and are also detected in this EIA, though at a lower also detected in this EIA, though at a lower
efficiency. ${ }^{18}$ Antibodies to Campylobacter jejuni were also measured by EIA. For this the antigen was prepared from Campylobacter jejuni using an acid glycine method as described by Kosunen et al ${ }^{20}$ Antibody titres of at least two Kosunen et al . Antit pulation from the Berlin area for at least IgG plus IgA or IgM were regarded as positive in the EIA and a titre of $\geqslant 1 / 320$ for the Widal test. Antibodies against Shigella flexneri were not looked for because a reliable test is not available. Antibodies against Chlamydia trachomatis were determined by a microimmunofluorescence test (MIF) ${ }^{21}$ : an Ig 1/64 with a positive IgA or a posig titre were regarded as positive. Chlamydia-specific antibodies were also analysed by a commercially available immunoperoxidase assay (IPA) (Ipazyme Chlamydia, Medac GmbH, Hamburg, Germany). ${ }^{22}$

BACTERIA IN STOOL AND UROGENITAL SWAB Stool samples of each patient were studied for the presence of yersinia, salmonella, shigella, and Campylobacter jejuni using established culture methods. For testing urogenital swabs for the presence of Chlamydia trachomatis samples samples

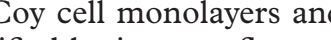
inclusion bodies identified by immunofluorescence labelled antibodies to chlamydia (Kallestad/Pathfinder, Kallestad Diagnsotics, Texas, USA).

CRITERIA FOR IDENTIFICATION OF TRIGGERING BACTERIUM

At the moment there are no generally accepted criteria for the identification of the triggering bacterium in ReA..$^{13} 24$ The criteria shown in table 2 , always in the presence of an asymmetrical arthritis, predominantly of the legs, were used in this study to make a diagnosis of ReA, is of ReA probably or possibly induced by Chlamydia trachomatis or by one of the enteric bacteria.

\section{Results}

FREQUENCY OF CAUSATIVE BACTERIA IN PATIENTS WITH REACTIVE ARTHRITIS

A causative pathogen was identified in 29/52 $(56 \%)$ of all patients with ReA (with a preceding symptomatic infection). Patients with ReA were further divided into enteric ReA (preceding enteritis, $\mathrm{n}=33$ ) and urogenic ReA (preceding urethritis/cervicitis, $\mathrm{n}=19)$. In $17 / 33(52 \%)$ of the patients with enteric ReA one of the enteric bacteria was identified, salmonella in $1 / 33(33 \%)$ and yersinia in $6 / 3$ (1) en in $12 / 19(63 \%)$ of the patients with urogenic ReA (fig 1).

Table 2 Criteria used for the identification of the triggering bacterium as a probable or possible cause of reactive arthritis (ReA); always in the presence of an arthritis either asymmetrically or predominantly of the legs

\begin{tabular}{|c|c|c|c|c|}
\hline & Chlamydia & Yersinia & Salmonella & Campylobacter \\
\hline \multirow[t]{3}{*}{ Probable $\operatorname{ReA}^{\star}$} & $\begin{array}{l}\text { Chlamydia positive in urogenital } \\
\text { smear plus symptomatic urethritis }\end{array}$ & Yersinia positive stool culture & Salmonella positive stool culture & $\begin{array}{l}\text { Camplyobacter positive stool } \\
\text { culture }\end{array}$ \\
\hline & $\begin{array}{l}\text { IgG } \geqslant 1 / 64 \text { plus positive IgA or } \\
\text { IgM } \dagger \text { plus chlamydia positive in } \\
\text { urogenital smear or symptomatic } \\
\text { urethritis }\end{array}$ & $\begin{array}{l}\text { Antibody titres of } 3 \mathrm{SD} \text { above } \\
\text { normalt for IgG plus IgA or IgM }\end{array}$ & $\begin{array}{l}\text { Antibody titres of } 3 \mathrm{SD} \text { above } \\
\text { normalt for IgG plus IgA or IgM }\end{array}$ & $\begin{array}{l}\text { Antibody titres of } 3 \mathrm{SD} \text { above } \\
\text { normalt for IgG plus IgA or IgM }\end{array}$ \\
\hline & $\begin{array}{l}\text { Antibody titres of } 2 \mathrm{SD} \text { above } \\
\text { normalt for IgG plus IgA or IgM } \\
\text { plus symptomatic enteritis or } \\
\text { Widal agglutination } \geqslant 1 / 320 \\
\text { (normal }<1 / 160)\end{array}$ & $\begin{array}{l}\text { Antibody titres of } 2 \mathrm{SD} \text { above } \\
\text { normalt for IgG plus IgA or IgM } \\
\text { plus symptomatic enteritis }\end{array}$ & $\begin{array}{l}\text { Antibody titres of } 2 \mathrm{SD} \text { above } \\
\text { normalt for IgG plus IgA or IgM } \\
\text { plus symptomatic enteritis }\end{array}$ & \\
\hline Possible ReA & $\begin{array}{l}\text { Chlamydia positive in urogenital } \\
\text { smear or IgG } \geqslant 1 / 64 \text { plus positive } \\
\text { IgA or IgM } \dagger\end{array}$ & $\begin{array}{l}\text { Antibody titres of } 2 \mathrm{SD} \text { above } \\
\text { normalt for IgG plus IgA or IgM } \\
\text { or Widal agglutination }>1 / 320 \\
\text { (normal }<1 / 160 \text { ) }\end{array}$ & $\begin{array}{l}\text { Antibody titres of } 2 \text { SD above } \\
\text { normalt for IgG plus IgA or IgM }\end{array}$ & $\begin{array}{l}\text { Antibody titres of } 2 \mathrm{SD} \text { above } \\
\text { normalt for IgG plus IgA or IgM }\end{array}$ \\
\hline
\end{tabular}




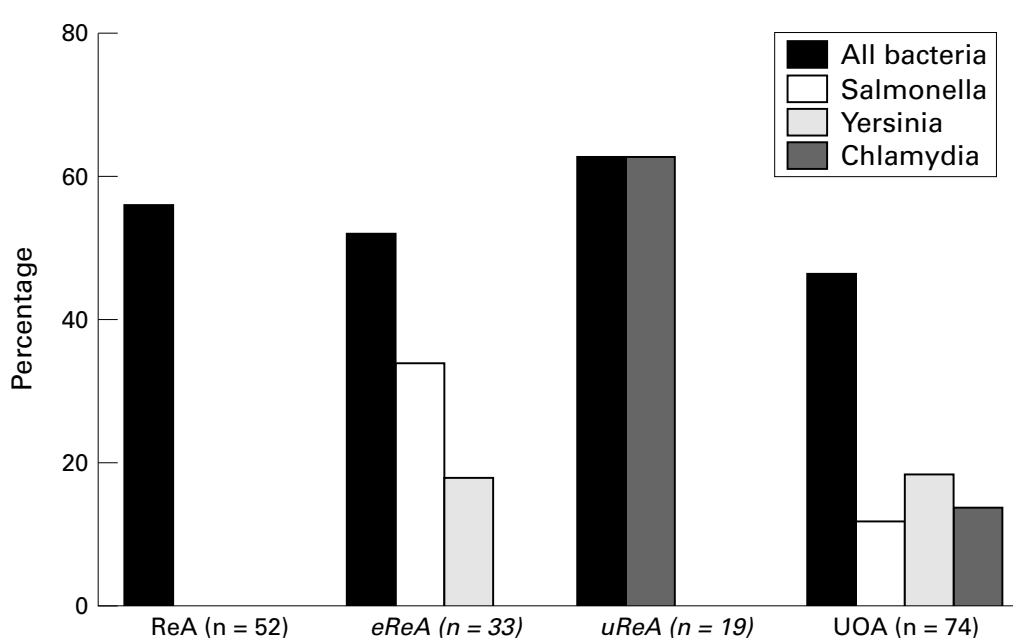

Figure 1 Frequency of all bacteria or single bacteria identified as responsible for enteri reactive arthritis $(e R e A)$, urogenic reactive arthritis $(u R e A)$, or undifferentiated positive anti-chlamydial MIF test and a positive yersinia serology, and one patient had a preceding urethritis, detection of Chlamydia trachomatis in a urogenital swab, a positive anti-chlamydial MIF test, preceding enteritis, trachomatis in a urogenital swa, a positive, and a positive yersinia serology. These patients, certainly the last one, probably had infection by two different pathogens as has been reported before. ${ }^{25}$ For the analysis, these patients were not included in any of the groups in which a causing bacterium was identified.

\section{DETECTION OF BACTERIA IN STOOL OR}

UROGENITAL TRACT

In $3 / 33(9 \%)$ patients with an enteric ReA the stool culture was positive for one of the enteric bacteria (two for salmonella, one for yersinia, none for campylobacter or shigella). All three patients also had a positive serology for the responsible bacterium. However, a positive stool culture was not found in any of the patients with UOA or urogenic ReA.

Chlamydia trachomatis was detected in the urogenital tract in $6 / 12(50 \%)$ patients with urogenic ReA but also in $4 / 74$ (5\%) patients with UOA.

COMPARISON OF TESTS AND CLINICAL SYMPTOMS IN PATIENTS WITH YERSINIA OR SALMONELLA INDUCED ARTHRITIS

In 20 patients yersinia and in 20 patients salmonella was identified as the causative bacterium for arthritis. A positive serology showed terium for arthritis. A positive serology showed a sensitivity of $90 \%$ for patients with yersinia induced arthritis and of $95 \%$ for patients with salmonella induced arthritis (fig 2). This indicates that in most of the patients the diagnosis was based on serology because-in contrast with chlamydia induced ReA contrast with chlamydia induced ReAcultures for these bacteria were rarely positive (fig 2). In less than $5 \%$ of a local healthy control population a positive serology for yersinia or salmonella was found, resulting in a good specificity of about $95 \%$ for these tests. When a cut off point of 3SD above the mean of a control population was used there was only a small difference for the used tho difference for the salmonella EIA but a difference of $30 \%$ for the yersinia EIA if compared with a cut off point of 2SD. However, the agglutination test (Widal) for the detection of yersinia antibodies (almost all IgM antibodies) had a low sensitivity of less than $20 \%$. A preceding diarrhoea was only reported in $35 \%$ of patients with yersinia induced arthritis but in $60 \%$ of patients with $60 \%$ arthritis (fig 2), indicating that triggering yersinia infections are associated more often with no symptoms or only minor symptoms ${ }^{10}$ compared with patients with salmonella infections. ${ }^{26} 27$

COMPARISON OF TESTS AND CLINICAL SYMPTOMS IN PATIENTS WITH CHLAMYDIA INDUCED ARTHRITIS

Chlamydia trachomatis was identified as the trigger for arthritis in 24 patients. In 12/24 $(50 \%)$ of these patients a preceding symptomatic urethritis/cervicitis was present (fig 2). In $10 / 24(42 \%)$ of all patients with chlamydia of these patients fulfilled the criteria tive anti preceding enteritis, three patients had a 

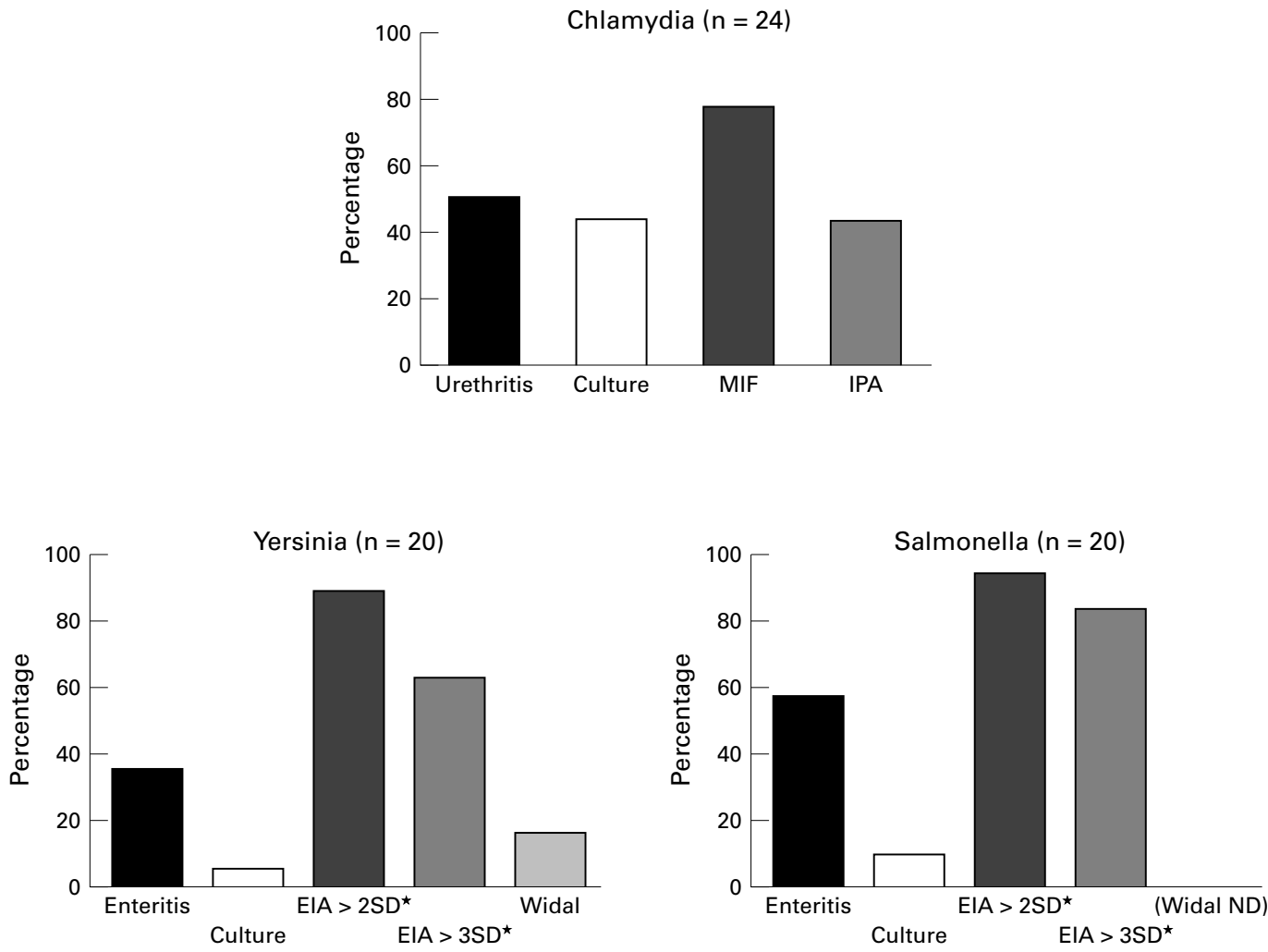

Figure 2 Percentage of symptoms or tests which were positive in patients with arthritis induced by chlamydia, yersinia, or salmonella (as defined in table 2). ${ }^{\star}$ Positive antibodies more than two or three standard deviations (SD) above the mean in a control population measured by a yersinia-specific or a salmonella-specific enzyme immunoassay (EIA). MIF = microimmunofluorescence test for the detection of Chlamydia trachomatis-specific antibodies; IPA = immunoperoxidase

induced ReA Chlamydia trachomatis was de- positive according to the criteria outlined in the tectable in the urogenital tract (fig 2). In 17/24 "Patients and methods" section in less than 5\% (71\%) serology was positive if MIF was used, of a local healthy population.

but only in 10/24 (42\%) of patients if the IPA In patients with preceding urethritis/ was used (fig 2). Antibodies specific for cervicitis the detection of Chlamydia trachomaChlamydia trachomatis measured by MIF were tis in the urogenital tract and the MIF had a
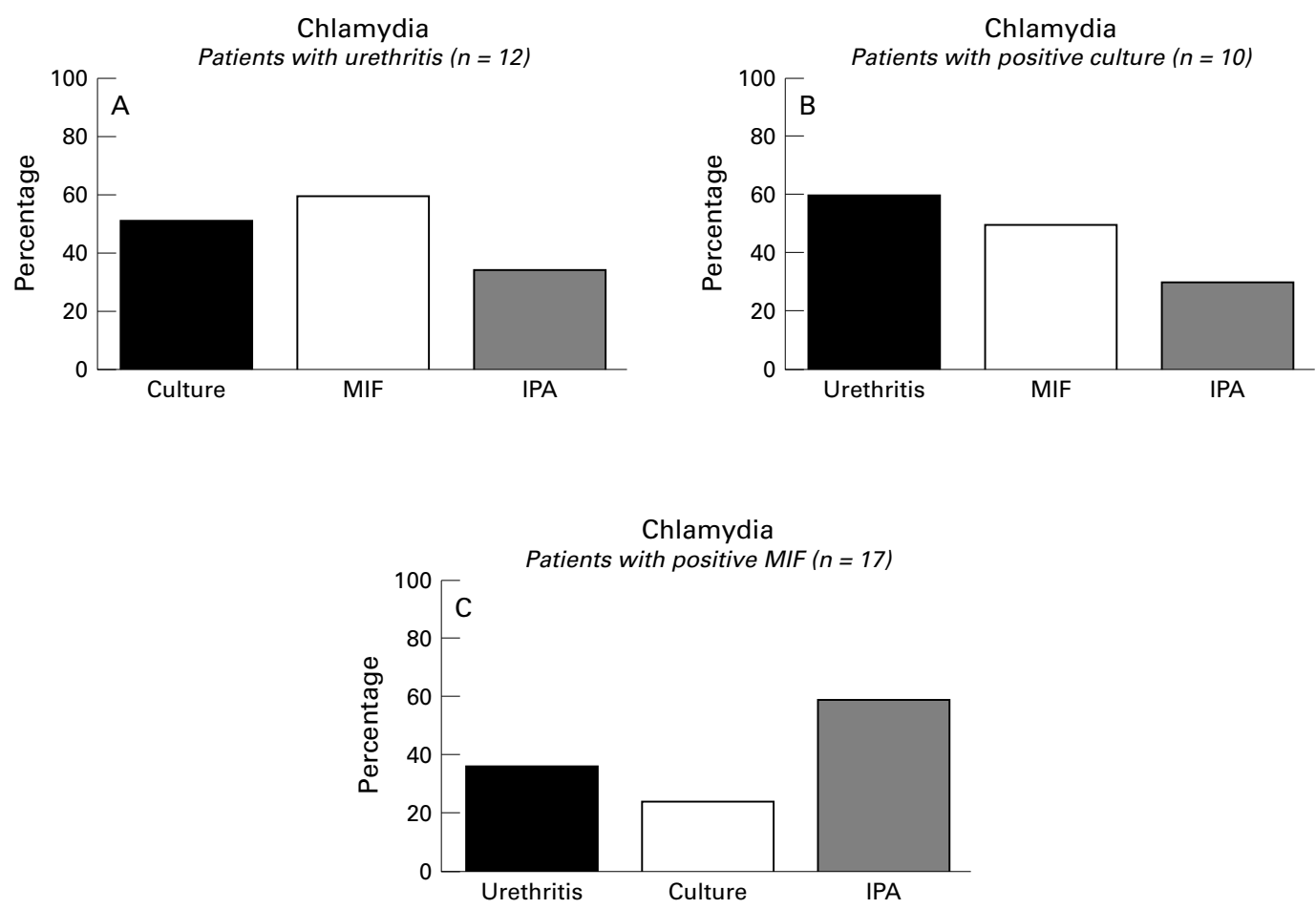

Figure 3 Frequency of other positive variables in patients with chlamydia induced arthritis with urethritis $(A)$, positive culture for chlamydia (B), or a positive microimmunofluorescence test (MIF) for the detection of chlamydia-specific 
similar sensitivity of $50-60 \%$ for the diagnosis of chlamydia induced arthritis, whereas the sensitivity was clearly lower for the IPA $(33 \%)$ (fig 3A). The detection of Chlamydia trachomatis in the urogenital tract correlated best with a preceding urethritis $(60 \%)$ and a positive MIF $(50 \%)$ but not so well with the IPA $(30 \%)$ (fig 3B). A positive MIF (detecting chlamydiaspecific antibodies) did not correlate well with a preceding urethritis (35\%), a positive culture $(24 \%)$, or with a positive IPA test $(59 \%)$, considering that the IPA test detects the same antibodies (fig 3C). Interestingly, of all the variables used in the diagnostic investigation for chlamydia induced arthritis, correlation of the variables with each other was only $60 \%$ or less (fig 3).

Discussion

We followed the recommendations made by the "Third International Workshop on Reactive Arthritis"13 and attempted to identify triggering bacteria in patients with ReA, which was gering bacteria in patients with $\mathrm{ReA}$, which was
defined by the presence of a symptomatic defined by the presence of a symptomatic
enteric or urogenic infection, and in patients with possible ReA, with the typical joint pattern but without a symptomatic preceding infection (UOA).

We identified the causative infection in 29/52 (56\%) patients with ReA. When the ReA was split into enteric and urogenic ReA, yersinia or salmonella were identified as the causative pathogen in $17 / 33(52 \%)$ patients with enteric ReA, salmonella being more common than yersinia. Patients with salmonella induced ReA more often had a symptomatic enteritis than patients with yersinia induced ReA. This is in line with previous reports showing that the gastrointestinal symptoms are absent or mild in ReA triggered by yersinia, ${ }^{10}$ whereas such symptoms are more severe and of longer duration in patients with salmonella induced ReA compared with salmonella infection without arthritis. ${ }^{26} 27$

However, none of the patients was positive for campylobacter or shigella. Surprisingly, we did not have a single case of arthritis induced by Campylobacter jejuni, even though it is a common cause of enteritis in Berlin. It remains to be determined whether this reflects a very low prevalence of campylobacter induced arthritis or, rather, a low sensitivity of the serological test used. In contrast, shigella is not a likely cause of enteritis and ReA in Germany except among people travelling to areas with a poor standard of hygiene. Furthermore, no good serology is available for the diagnosis of shigella infections. Therefore, we might have missed single cases because we had to rely only on positive stool cultures.

Even more interestingly, a triggering bacterium was also identified in $35 / 74(47 \%)$ patients with UOA, yersinia being slightly more common $(19 \%)$ than salmonella $(12 \%)$ or Chlamydia trachomatis (16\%). Fifty per cent of these patients were positive for HLA-B27, a similar number as for the ReA group, indicating that these patients had the same disease.

There have been two comparable studies in the past. Kvien et al also identified a triggering bacterium in $40-50 \%$ of patients with probable or possible ReA. ${ }^{4}$ Chlamydia trachomatis was the most common ( $22 \%$ of patients), followed by yersinia and salmonella ${ }^{4}$ Hannu et al identitiggering bacterium in $27 / 60(45 \%)$ atients with possible ReA: yersinia in 10 patients, Chlamydia trachomatis in eight, Chlamydia pneumoniae in four, salmonella in three, and Camplyobacter jejuni in two patients. ${ }^{15}$ However, in both these studies the laboratory results were not clearly correlated with the presence or absence of a symptomatic by Kvien $e t a l^{4}$ no chlamydia-specific serology was used and in the study by Hannu $e t a l^{15}$ the only serology used for the diagnosis of salmonella or yersinia induced arthritis was the Widal agglutination test. Thus in both studie the frequency of the triggering bacterium might have been underestimated. Nevertheless, all these studies, including the present one, suggest that Chlamydia trachomatis, yersinia, and salmonella are the most common bacteria causing $\mathrm{ReA}$ and that these bacteria are also relevant in patients with the clinical picture of undifferentiated arthritis. Although yersinia is a relevant pathogen in continental Europe it seems to be rather rare in the United Kingdom and America.

There is currently no gold standard for the diagnosis of ReA such as histology for malignancies. None of the criteria used are generally accepted or have been evaluated properly. ${ }^{13}$ However, the criteria used for diagnosis in this study (table 2) resemble those used in recent tudies ${ }^{1415}$ and are, in the authors' opinion, ffici is is and are, in the authors' opinion, his study. Because an increase of bacteriaspecific antibodies was an important criterion for the identification of the triggering bacterium we have to be cautious with comment about the sensitivity of the serology in this study. None the less, the sensitivity for serological tests of about $90 \%$ (fig 2) seen in patients with positive stool culture the sensitivty of yersinia antibodies was about $100 \%$ in acute cases and still $84 \%$ after one year in yersinia induced $\operatorname{ReA}^{28}$ and about $92 \%$ for salmonella antibodies in the first year of a salmonella induced ReA. ${ }^{29}$ The high specificity of bout $95 \%$ for the three serological tests used EIA for infections with ella and the MIF for Chlamydia trachomatis) will have to be confirmed in future studies. Yersinia-specific IgG plus IgA or IgM antibodes has been found before in a healthy German population in about $10 \%$, resulting in a specificity of $90 \%{ }^{30}$ Thus these tests seem to be useful for the diagnosis of ReA. In future studies he specificity of these tests should also be evaluated in comparison with other arthritides (and not only healthy controls as in this study) which might be considered in the differentia diagnosis of ReA.

When we compared a cut off point of 2SD with a cut off point of $3 \mathrm{SD}$ for a positive test there was mainly a difference for yersinia serolgu salmonella serology. 
off point of 2 or 3SD should be used. Obviously, a higher cut off point improves specificity but loses sensitivity. Not surprisingly, the Widal test for the detection of yersiniaspecific antibodies showed only a low sensitivity. It has been known for a long time that if only IgG and IgA class antibodies are present the agglutination test may remain negative. This has been shown to be true also for antibodies against yersinia. ${ }^{32}$ In this earlier study only 22 out of 53 serum samples which were strongly positive for Yersinia enterocolitica as determined by measurement of IgG and IgA class antibodies in EIA showed a positive reaction in the bacterial agglutination tests. Because of this, the agglutination test is only useful in acute infections but not in more chronic disease. We did not include the Widal test for salmonella-specific antibodies because a low sensitivity for more chronic cases had been previously reported. ${ }^{18}$

The MIF seems to be still the best serological test for chlamydia-specific antibodies." This is also supported by the high specificity found in our study. However, because it is laborious and therefore expensive it is not in general use. Various other tests, mainly EIA, using whole Chlamydia trachomatis antigen or chlamydia-specific tein or lipopolysaccharide are used instead. Unfortunately, these tests have a relatively low specificity and sensitivity for the diagnosis of chlamydia induced arthritis of about $78 \%$ and $73 \%$, respectively. ${ }^{33}$ In our study one of the commercially available immunoperoxidase assays also had a low sensitivity for the diagnosis of chamydia induced arthitis. Only $59 \%$ of patients with a positive MIF were also positive when the IPA was applied. This discrepancy when the IPA was applied. This discrepancy
shows that there is a need for an improved shows that there is a need for an improved serological test which can be applied for the daily clinical practice.

For the diagnosis of enteric ReA, a search for the triggering bacterium in stool cultures seems to be useful only in patients with a preceding symptomatic enteritis but not in patients with the clinical picture of UOA. Yersinia or salmonella was detected in the stool in $9 \%$ of patients who had diarrhoea in the preceding four weeks but in none of the patients without preceding gut symptoms. In an earlier report salmonella was found in $4 \%$ of patients with possible ReA, but again it was not differentiated in this study between patients with and without diarrhoea. ${ }^{4}$

The situation is different for Chlamydia trachomatis. In $63 \%$ of patients with a urogenic ReA Chlamydia trachomatis could be identified as the triggering bacterium, a figure similar to hat of earlier reports. ${ }^{35}{ }^{36}$ However, the detection of Chlamydia trachomatis contributed to diagnosis also in four patients with UOA. Thus in a diagnostic investigation of patients with ReA a search for Chlamydia trachomatis in the urogenital tract should be included. This is now easier and cheaper because Chlamydia trachomatis can be found in the first portion of the morning urine with a sensitivity close to that of other methods. ${ }^{3738}$
In chlamydia induced arthritis diagnosis was based on the presence of a preceding symptomatic urethritis/cervicitis, a positive MIF for the detection of chlamydia-specific antibodies, and/or on the detection of Chlamydia trachomais in the urogenital tract. However, there was only a poor overlap between these variables (fig 3), indicating that all three should be used in a diagnostic investigation for chlamydia induced arthritis.

In this study we did not look for Chlamydia neumoniae as a causative agent of arthritis. Chlamydia pneumoniae can also induce ReA, ${ }^{15} 3940$ though clearly less often than Chlamydia trachomatis. ${ }^{15} 404$

The PCR method was not used in this study because testing for enteric bacteria in the joint is normally negative and the possible value of PCR testing for chlamydia was not clear at the start of this study (discussed by Sieper et $a l^{42}$ ). However, Chlamydia trachomatis has been detected in synovial fluid or synovial membrane by PCR in up to $30 \%$ of patients with undifferentiated arthritis ${ }^{41} 4344$ and is thus promising diagnostic tool for the future, though there is currently no agreement on the optimal technique for using the chlamydiaspecific PCR..$^{45}$ However, it must be emphasised that the specificity of this method has to be further clarified because Chlamydia trachomatis was also found by PCR in the joints of healthy controls. ${ }^{46}$

In conclusion, the data presented here underline the fact that ReA is an importan differential diagnosis in patients with undifferentiated arthritis and that in most cases the triggering bacterium can be identified. Thus a prospective study for the definition and evaluaria for the diag nosis of ReA is urgently needed. In the meantime, the data presented here on the frequency of single bacteria associated with ReA and the discussion about the tests used for diagnosis may be helpful.

\footnotetext{
1 Sieper J, Braun J. Reactive arthritis. Curr Opin Rheumatol
1999;11:238-43.
2 Sieper J, Kingsley GH, Märker-Hermann E. Aetiological Sieper J, Kingsley GH, Märker-Hermann E. Aetiologica
agents and immune mechanisms in enterogenic reactive Dougados M, van der Linden S, Juhlin R, Huitfeldt B, Amor
B, Calin A, et al. The European Spondylarthropathy Study Group preliminary criteria for the classification of spondy 4 Kvien TK, Glennas A, Melby K, Granfors K, Andrup O, Karstensen B, et al. Reactive arthritis: incidence, triggerin agents and chical presentatin. J Rheunatol 1994;2

Hülsemann JL, Zeidler H. Undifferentiated arthritis in an early synovitis
1995;13:37-433

6 El-Gabalawy HS, Goldbach-Mansky R, Smith D, Arayssi T Bale S, Gulko P, et al. Association of HLA alleles and cliniArthritis Rheum 1999;42:1696-705.

7 Wilkens RF. Reiter's syndrome: evaluation of preliminary criteria

8 Amor B. Reiter's syndrome and reactive arthritis. Clin Ex Rheumatol 1984;2:315-19.

thropathies. Reiter's syndrome. In: Calin A, ed. Spondyloarthropat $119-50$

Lahesmaa-Rantala R, Toivanen A. Clinical spectrum of reactive arthritis. In: Toivanen A, Toivanen P, eds. Reactic
arthritis. Boca Raton: CRC Press Inc, 1988:1-13. 1 Khan MA. An overview of clinical spectrum and heteroge- 
12 Sieper J, Braun J, Brandt J, Miksits K, Heesemann J, Laitko lia in undifferentiated oligoarthritis. J Rheumatol 1992;19: $1236-42$.

13 Kingsley G, Sieper J. Third International Workshop o Reactive Arthritis. $23-26$ September 1995, B Berlin, Ger-
many. Report and abstracts. Ann Rheum Dis 199655:564ma.

Lauhio A, Leirisalo-Repo M, Lahdevirta J, Saikku P, Repo H. Double-blind, placebo-controlled study of three-month
treatment with lymecycline in reactive arthritis, with special reference to chlamydia arthritis. Arthritis Rheum 1991;34: 6-14. Hannu T, Puolakkainen M, Leirisalo-Repo M. Chlamydia
pneumoniae as a triggering infection in reactive arthritis. pneumoniae as a triggering infection in reactive arthritito
Rheumatology 1999;38:411-14.

6 Sieper J, Fendler C, Laitko S, Sorensen H, Gripenber ciprofloxacin treatment in patients with reactive arthriti and undifferentiated oligoarthritis: a three-month, multicenter, double-blind, randomized, placebo-controlled
study. Arthritis Rheum 1999;42:1386-96.

17 Mäki-Ikola O, Lahesmaa R, Heesemann J, Merilahti-Palo $\mathrm{R}$, Saario R, Toivanen A, et al. Yersinia-specific antibodies in serum and synovial fluid in patients with yersinia-
triggered reactive arthritis. Ann Rheum Dis 1994;53: 535-9.

18 Isomäki O, Vuento R, Granfors K. Serological diagnosis of salmonella infections by enzyme immunoassay. Lancet
1989;i:1411-14. 9 Mäki-Ikola O, G

20 arthritis. Lancet 1992;339:1096-8. Kosunen TU, Rautelin H, Pitkanen T, Ponka A, Petterso
T. Antibodies against an acid extract from a single campystrain in hospitalized campylobacter Infection 1983;11:189-91.
Wang SP, Grayston JT. Human serology in Chlamydi Infect Dis 1974;130:388-97.

Vevenini R, Sarov I, Rumpianesi F, Donati M, Melega Varotti C, et al. Serum specific IgA antibody to Chlamyd by ELISA and an immunofluorescence test J Clin Pathol 1984;37:686-91

23 Pacheco-Tena C, Burgos-Vargas R, Vazquez-Mellado J, of patients for clinical and exper arthritis. J Rheumatol 1999;26:1338-46.
Sieper J, Braun J. Problems and advances in the diagnosis of 5 Konttive arthritis. J Rheumatol 1999;26:1222-4. Santavirta S. Occurrence of different ensuing triggering
infections preceding reactive arthritis: a follow up study. infections preceding reactive arthritis. a folng
BMJ 1988;296:1644-5.

26 Inman RD, Johnston ME, Hodge M, Falk J, Helewa Postdysenteric reactive arthritis. A clinical and immunoge-
netic study following an outbreak of salmonellosis. Arthritis heum 1988;31.1377-83.

DA, Hodge MA, Rajanayagam C Inman RD. Post-salmonella reactive arthritis: late clinical
sequelae in a point source cohort. Am J Med 1995;98:1321. ence of IgM, IgG, and IgA antibodies to yersinia in yersinia
arthritis. J Infect Dis 1980;141:424-9. 9 Mäki-lkola O, Leirisalo-Repo M, Kantele A, Toivanen P, Granfors K. Salmonella-specific antibodies in reactive
arthritis. J Infect Dis 1991;164:1141-8.
30 Mäki-Ikola O, Heesemann J, Toivanen A, Granfors K. High Finland and Germany. Rheumatol Int 1997; 16:227-9. Wilkinson PC. Immunoglobulin patterns of antibodies
against brucella in man and animals. J Immunol 1966;96:
457-63. $457-63$.

Granfors K, Toivanen A. ELISA and RIA for serologic diagnosis of yersiniosis. Rev Infect Dis 1984;6:421-4.
Bas S, Cunningham T, Kvien TK, Glennas A, Melby K, Vischer TL. The value of isotype determination of serum reactive arthritis. Br J Rheumatol 1996;35:542-7. Bas S, Vischer TL. Chlamydia trachomatis antibody detec-
tion and diagnosis of reactive arthritis. Br J Rheumatol tion and diagnosis of reactive anthitis. Br J Rhy detato
1998; 1054-9.

35 Keat AC, Thomas BJ, Taylor-Robinson D, Pegrum GD, Maini RN, Scott JT. Evidence of Chlamydia trachomatis
infection in sexually acquired reactive arthritis. Ann Rich E, Hook EW, Alarcon GS, M arthritis in patients attending an urban sexually transmitte
diseases clinic. Arthritis Rheum 1996.39:1172 37 Rabenau H, Berger A, Doerr HW, Weber B. Testing for 38 Gaydos CA, Howell MR, Pare B, Clark KL, Ellis DA, Hendrix RM, et al. Chlamydia trachomatis infections in female military recruits. N Engl J Med 1998;339:739-44.
39 Braun J, Laitko S, Treharne J, Eggens U, Wu P, Distler A, et al. Chlamydia pneumoniae- a new causative agent of reac-
tive arthritis and undifferentiated oligoarthritis. Ann Rheum Dis 1994;53:100-5.

HC, Arayssi TK. Lower prevalence of Chlamydia pneumoniae DNA compared with
Chlamydia trachomatis DNA in synovial tissue of arthritis patients. Arthritis Rheum 1999;42:1889-93.
Wilkins.

Wack on NZ, Kingsley GH, Sieper J, Braun J, Ward ME. trachomatis DNA in synovial fluid from patients with range of rheumatic diseases and the presence of an anti-
chlamydial immune response. Arthritis Rheum 1998;41

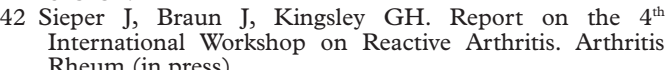

3 Bas S, Griffais R, Kvien TK, Glennas A, Melby K, Vischer TL. Amplification of plasmid and chromosome chlamydia DNA in synovial fluid of patients with reactive arthritis and
undifferentiated seronegative oligoarthropathies. Arthritis

Branigan PJ, Gerard HC, Hudson AP, Schumacher HR Jr
Pando J. Comparison of synovial tissue and synovial fluid as the source of nucleic acids for detection of Chlamydia (arthritis Rheum 5 Kuipers JG, Nietfeld L, Dreses-Werringloer U, Koehler L Wollenhaupt $\mathrm{J}$, Zeidler $\mathrm{H}$, et al. Optimised sample prepara tis DNA by polymerase chain reaction. Ann Rheum Dis 1999;58:103-8.

6 Schumacher HR Jr, Arayssi T, Crane M, Lee J, Gerard H, be found in the synovium of some asymptomatic subjects. Arthritis Rheum 1999;42:1281-4.
Braun J, Bollow M, Remlinger G, Eggens U, Rudwaleit M, Braun J, Bollow M, Remlinger G, Eggens $\mathrm{U}$, Rudwaleit $\mathrm{M}$
Distler, et al. Prevalence of spondylarthropathies in Distler, et al. Prevalence of spondylarthropathies in
HLA-B27 positive and negative blood donors. Arthritis
Rheum 1998;41:58-67. 